\title{
DIGITALCOMMONS

\section{A Review and New Framework for Instructional Design Practice Variation Research}

\author{
Hillary Leigh \\ Wayne State University, hnleigh@gmail.com \\ Monica W. Tracey \\ Wayne State University, Monicatracey@wayne.edu
}

\section{Recommended Citation}

Leigh, H. N., \& Tracey, M. W. (2010). A review and new framework for instructional design practice variation research. Performance Improvement Quarterly, 23(2), 33-46.

Available at: http://digitalcommons.wayne.edu/coe_aos/19 
A Review and New Framework for Instructional Design Practice Variation Research

\author{
Hillary N. Leigh \\ Wayne State University \\ 562-331-2332 \\ hleigh@wayne.edu \\ Monica W. Tracey \\ Wayne State University \\ 313-577-1700 \\ monicatracey@wayne.edu
}


A Review and New Framework for Instructional Design Practice Variation Research Abstract

This article reviews practice variation in the field of instructional design. First, it compares instructional designer practice as reported or observed in several classic research studies. This analysis is framed by the standards established by the IBSTPI competencies for planning and analysis, design and development, implementation and management. Although no certain causal linkages exist, we briefly review some of the reasons posited in the literature to explain ID practice variation (i.e. lack of time and resources, control in decision-making, the designer's perception of a task, underlying philosophical beliefs, and designer expertise). Limitations of the literature-base are explored, followed by a proposal for an alternative view of ID practice variation and recommendations. 
Hillary N. Leigh is a doctoral student in Wayne State University's instructional technology program. Her research interests include evidence-based intervention selection and justification for the field of performance improvement. Her dissertation topic relates to practitioners' usage of scientific and artistic evidential sources in selecting an intervention. She has consulted with health care, educational, and retail organizations to select, develop, implement, and evaluate a variety of instructional and non-instructional interventions. E-mail: hleigh@wayne.edu

Monica W. Tracey is an Associate Professor of Instructional Technology in the College of Education at Wayne State University. Her teaching and research experience center on the theory of instructional design and development and its applications. Tracey has over 16 publications including book chapters and journal articles in the area of instructional design and performance improvement. Tracey is currently directing a large scale cross-cultural customized instructional design and performance improvement project in Dubai, The United Arab Emirates. Email: MonicaTracey@wayne.edu 
Instructional design (ID) is a purposeful activity to facilitate learning through a combination of strategies, activities, and resources (Sims \& Koszalka, 2008). ID is performed by individuals who hold various job titles and roles (Davidson-Shivers \& Rasmussen, 2007; Richey, Fields, \& Foxon, 2001). For example, Larson and Lockee (2004) examined ID roles in the corporate, higher education, K-12 education, and government environments and found that among other titles, professional instructional designers may be referred to as instructional technologists, distance learning coordinators, librarians, media specialists, or instructional system specialists. Given the wide array of job titles used to refer to ID practitioners, it is not surprising to find that there are many different approaches advocated for ID practice. In fact, many authors have presented in the literature surveys or taxonomies of various ID models, c.f. Molenda and Russell (2006), Gustafson and Branch (2002), and Seels and Richey (1994). Further corroborative support for the varying ways in which ID can be approached and executed is demonstrated by a number of classic empirical studies of variation in ID practice (Kirschner, van Merriënboer, Sloep, \& Carr, 2002; Rowland, 1992; e.g. Tessmer \& Wedman, 1992; Visscher-Voerman \& Gustafson, 2004; Wedman \& Tessmer, 1993).

With the International Board for Training, Performance, and Instruction (IBSTPI) competencies as a conceptual framework, this article considers both the general extent to which instructional designers perform various ID activities and the types of gaps that exist between actual and ideal ID practice. Then, we explore explanations offered in the literature for causes of these discrepancies. This review forms the basis for a proposal for an alternative characterization of practice variation.

"Ideal" Practice 
Our initial analysis defines ideal ID practice in terms of instructional design competencies. Competencies are internal capabilities or characteristics that are observed via behaviors in a job role (McLagan, 1989, as cited in Rothwell, 1999). The current and most widely accepted competency standards for instructional design were developed by the International Board for Training, Performance, and Instruction (IBSTPI) (Richey, Fields, \& Foxon, 2001). IBSTPI defines a competency as "a knowledge, skill, or attitude that enables one to effectively perform the activities of a given occupation or function to the standards expected in employment" (Richey, Fields, \& Foxon, 2001, p. 31).

These competencies are organized into four domains and classified by the level of designer experience, as shown in Table 1.

\section{Table 1}

IBSTPI Standards for Instructional Designer Competency

\begin{tabular}{|c|c|c|}
\hline Domain & Essential competencies & Advanced competencies \\
\hline $\begin{array}{l}\text { Professional } \\
\text { foundations }\end{array}$ & $\begin{array}{l}\text { 1. Communicate effectively in } \\
\text { visual, oral and written form } \\
\text { 2. Update and improve one's } \\
\text { knowledge, skills and } \\
\text { attitudes pertaining to } \\
\text { instructional design and } \\
\text { related fields }\end{array}$ & $\begin{array}{l}\text { 1. Apply current research and } \\
\text { theory to the practice of } \\
\text { instructional design } \\
\text { 2. Apply fundamental research } \\
\text { skills to instructional design } \\
\text { projects } \\
\text { 3. Identify and resolve ethical } \\
\text { and legal implications of } \\
\text { design in the work place }\end{array}$ \\
\hline $\begin{array}{l}\text { Planning and } \\
\text { analysis }\end{array}$ & $\begin{array}{l}\text { 1. Conduct a needs } \\
\text { assessment } \\
\text { 2. Design a curriculum or } \\
\text { program } \\
\text { 3. Select and use a variety of } \\
\text { techniques for determining } \\
\text { instructional content } \\
\text { 4. Identify and describe target } \\
\text { population characteristics } \\
\text { 5. Analyze the characteristics of } \\
\text { the environment } \\
\text { 6. Analyze the characteristics of }\end{array}$ & \\
\hline
\end{tabular}




\begin{tabular}{|c|c|c|c|}
\hline & 7. & $\begin{array}{l}\text { existing and emerging } \\
\text { technologies and their use in } \\
\text { an instructional environment } \\
\text { Reflect on the elements of a } \\
\text { situation before finalizing } \\
\text { design solutions and } \\
\text { strategies }\end{array}$ & \\
\hline $\begin{array}{l}\text { Design and } \\
\text { development }\end{array}$ & 1. & $\begin{array}{l}\text { Select and use a variety of } \\
\text { techniques to define and } \\
\text { sequence the instructional } \\
\text { content } \\
\text { Select or modify existing or } \\
\text { develop new instructional } \\
\text { materials } \\
\text { Develop instructional } \\
\text { materials } \\
\text { Design instruction that } \\
\text { reflects and understanding of } \\
\text { the diversity of learners and } \\
\text { groups of learners } \\
\text { Evaluate and assess } \\
\text { instruction and its impact }\end{array}$ & $\begin{array}{l}\text { 7. Select, modify or create a } \\
\text { design and development } \\
\text { model appropriate for a given } \\
\text { project } \\
\text { 8. }\end{array}$ \\
\hline $\begin{array}{l}\text { Implementation } \\
\text { and } \\
\text { management }\end{array}$ & 1. & $\begin{array}{l}\text { Provide for the effective } \\
\text { implementation of instructional } \\
\text { products and programs }\end{array}$ & $\begin{array}{l}\text { 9. Plan and manage } \\
\text { instructional design projects } \\
\text { 10. Promote collaboration, } \\
\text { partnerships and } \\
\text { relationships among the } \\
\text { participants in a design } \\
\text { project } \\
\text { 11. Apply business skills to } \\
\text { managing instructional } \\
\text { design } \\
\text { 12. Design instructional } \\
\text { management systems }\end{array}$ \\
\hline
\end{tabular}

Note. From Instructional Design Competencies: The Standards (pp. 46-55), by R.C. Richey, D.C. Fields, and M. Foxon, 2001.

The intention of the IBSTPI was to provide a guide for professional practice for "someone who may or may not have had formal academic training in the field, but probably did have considerable training and exposure to the literature of the field" (Foshay, 2000, p. xxii). 
Using the IBSTPI competencies as a framework for examining ID practice was justified in a number of ways. A key assumption during the formulation of the standards was that they represented normative guidelines for practice. Richey, Fields, and Foxon (2001) note that while both consensus-oriented and model-building processes were used in the development of the competencies, the approach emphasized an idealistic element: "ID competencies define the manner in which design should be practiced" (p. 41). Furthermore, the IBSTPI competencies have been used as a conceptual framework in previous empirical studies in the field. For example, the IBSTPI standards were used by Chase (2002) as a lens for interpreting gender differences in instructional design expertise. More recently, Johnson (2005) investigated issues related to the professional development and education of instructional designers through an analysis of the extent to which the IBSTPI competencies are addressed in graduate curricula.

Although the IBSTPI competency domains were used as the primary organizer for this review, two adjustments were made. First, reflecting the view of the expanded importance of evaluation in instructional design (Dick \& Johnson, 2007), ' formative and summative evaluation' was included as its own domain (rather than including it with 'design and development'). Second, the 'professional focus' domain was eliminated from our review. This decision was grounded in the view that the behaviors associated with professional focus are not unique to ID, nor are they typically included in studies of instructional designers' practice. Still, we hold that professionalism remains an essential component of ID practice. In fact, the second reason (i.e. lack of inclusion in ID practice studies) suggests that professional focus merits future study in the field.

\section{Practice Variation}


Within this modified framework, this section discusses studies of ID practice variation in the following domains of ID practice: (a) planning and analysis, (b) design and development, (c) formative and summative evaluation, and (d) implementation and management. Research on instructional designers' practice in each domain will be discussed in turn.

\section{Planning and Analysis}

In this domain, IBSTPI set forth seven competencies related to needs assessment, program design, determining instructional content, assessing learner characteristics, environmental analysis, use of emerging technologies, and reflecting on the situation-at-hand prior to finalizing decisions; all of which were deemed essential. Despite this, there appears to be a great deal of variation in the practice of the activities outlined in the IBSTPI competencies related to planning and analysis. For instance, needs assessments are conducted infrequently. An initial set of findings from Tessmer and Wedman (1992) and Wedman and Tessmer (1993) found that only $29 \%$ of designers reported that they always conducted needs assessments (p.48). Replications of this study reported slightly lower rates of needs assessment activity. Winer, Vasquez-Abad, and Tessmer (1994) indicated that needs assessment was performed in only $26 \%$ of cases and Mann (1996) found that 27\% of instructional designers reported always using needs assessment. Only one of the five teams observed by Kirschner, van Merriënboer, Sloep and Carr (2002) planned to perform a general needs assessment as the initial step to course design and development (p. 101). In fact, there was almost unanimous agreement by the instructional designers participating in this study $(N=15)$ that the initial step of instructional design should be based on learner needs (rather than content-based) but individual teams' approaches to the design task varied by organizational context. The other two university-based design teams started their design process with producing a project plan for client approval and an analysis of organizational 
policy best practices to develop a competency map. The two teams from the business consulting organization both carried out a task analysis - although their specific methods for doing so varied between both teams (pp. $100-101)$.

When needs assessments are conducted, they are performed in a limited manner (Holcomb, Wedman, \& Tessmer, 1996; Visscher-Voerman \& Gustafson, 2004). Holcomb, Wedman, and Tessmer (1996) found both a higher rate of needs assessment completion (60\%) and high average degree of implementation (6.6) $(S D=2.5)$ but designers participating in the study rated the thoroughness of these needs assessments on a scale of 1 to 10 , with 1 being 'hardly gave it any thought at all' and 10 being 'as thoroughly as possible' (p. 56). Furthermore, Visscher-Voerman and Gustafson (2004) observed that 19 of the 24 instructional designers carried-out abbreviated analyses of approximately one day, noting that in general, "analysis activities resulted in further specification of a potential solution rather than a specification of a problem" (p. 73).

Additionally, practices related to the development and weighing of alternative solutions vary from ID specifications and between designers. In the case of the former, Visscher-Voerman and Gustafson (2004) found that designers rarely performed this activity at a broad level; rather they tended to examine various options within a specific solution (p. 74). At the designer level, both novice and expert designers generate solutions quickly, but expert designers used these alternatives to create boundaries of analysis (Rowland, 1992, p. 80).

Finally, the practice of assessing learner characteristics is inconsistent amongst designers. Respectively, Tessmer and Wedman (1992), Wedman and Tessmer (1993), and Holcomb et al. (1996) found it to be the least and second least frequently performed planning and analysis 
activity. While Winer, Vasquez-Abad, and Tessmer (1994) rank it near the middle, planning and analysis tied for the fifth least performed activity out of eleven total activities.

\section{Design and Development}

The competency statements related to this domain deal with the use of ID models, sequencing content, selecting or modifying materials, developing materials, awareness of learner diversity, and evaluation. As previously noted, evaluation will be addressed separately.

The practice of developing specific learning objectives is a performance included within these greater competencies (Richey, Fields \& Foxon, 2001). This task, drafting objectives, is the most commonly activity performed by instructional designers (Mann, 1996; Tessmer \& Wedman, 1992; Wedman \& Tessmer, 1993; Winer, Vasquez-Abad, \& Tessmer, 1994). In each of these studies, this activity was reportedly always performed by the largest percentage of respondents, $66 \%, 82 \%$, and $76 \%$ respectively. Holcomb et al. (1996) support the extensiveness of this activity in instructional design, as in their sample $(N=40), 95 \%$ reported in an interview that they had established learning objectives during a recently completed ID project (p. 56).

The frequency with which designers perform other design and development activities such as selecting instructional strategies and media, identifying learning outcomes and preparing test items varies greatly. Table 2 summarizes the findings of Tessmer and Wedman (1992), Winer, Vasquez-Abad, and Tessmer (1994), and Mann (1996) in regard to the percentage of respondents that indicated that they always performed these activities.

Table 2

Design and Development Activities Compared Across Studies

\begin{tabular}{lll}
\hline Activity & Tessmer and & Winer, Vasquez- \\
& Wedman (1992), & Abad, and
\end{tabular}




\begin{tabular}{lccc}
\hline & \multicolumn{3}{c}{ Tessmer (1994) } \\
\hline Identifying & $36 \%$ & $52 \%$ & $27 \%$ \\
learning outcomes & & & \\
\hline Writing test items & $59 \%$ & $44 \%$ & $4 \%$ \\
\hline Selecting & $50 \%$ & $64 \%$ & $27 \%$ \\
instructional & & & \\
strategies & & & \\
\hline Selecting & $52 \%$ & $62 \%$ & $26 \%$ \\
instructional & & & \\
media & & & \\
\end{tabular}

Of note, Holcomb et al. (1996) found that $71 \%, 75 \%, 92 \%$, and $70 \%$ of their participants reported having completing these respective activities during a recent ID project, but this subtle change to the question posed to study participants, collection of data via interviews, and sampling of a single organization make direct comparisons between Holcomb et al's findings and the previous studies questionable — as differences in the reported performance of strategy and media selection, learning outcome, and test item construction activities may be due to bias introduced by these methods or genuine differences in the context (either the design projects themselves or the unique organization). In fact, none of these studies' findings—alone or in concert—seem to suggest widespread, consistent application of these standards in ID practice. In further support of this position, Visscher-Voerman and Gustafson (2004) observed that the identification of learning outcomes and test item development were often delegated to subject 
matter experts; also, media decisions were frequently made prior to the beginning of a design project and only rarely involved instructional designers in this process.

\section{Formative and Summative Evaluation}

As previously mentioned, the IBSTPI competencies include evaluating the impact of instruction as a competency within the design and development domain, but due to a growing focus on evaluation it is handled separately here. In regard to the use of various types of evaluation in the field, only Wedman and Tessmer (1993) and Winer, Vasquez-Abad, and Tessmer (1994) studied the frequency with which both elements of formative and summative evaluation were always used. As indicated in Table 3, the percentage of designers who report doing so is relatively low.

Table 3

\section{Comparison of Evaluation Activities}

\begin{tabular}{|c|c|c|}
\hline Activity & $\begin{array}{c}\text { Wedman and Tessmer } \\
(1993)\end{array}$ & $\begin{array}{c}\text { Winer, Vasquez-Abad, } \\
\text { and Tessmer (1994) }\end{array}$ \\
\hline Pilot-testing & $33 \%$ & $33 \%$ \\
\hline Follow-up evaluation & $38 \%$ & $22 \%$ \\
\hline
\end{tabular}

Mann (1996) did not study follow-up evaluation, but reported a slightly higher rate of 44\%, for pilot testing (p. 460). Holcomb et al. (1996) reported that follow-up evaluation was used by $34 \%$ of participants and a markedly higher rate of formative evaluation, 92\% (p. 56).

\section{Implementation and Management}

This domain includes competencies pertaining to managing instructional design projects, collaboration with stakeholders, business skills, learning management systems, and 
implementation. Effective implementation is integral to creating change (Malopinksy \& Osman, 2006; Moseley \& Hastings, 2005), yet instructional designers rarely play a role in it. According to Visscher-Voerman and Gustafson (2004), designers plan for implementation throughout design by involving stakeholders and providing information about the design process and products, but are only occasionally involved in the implementation of instruction; furthermore, the sense of personal accountability for successful implementation varies from designer to designer (p.75). A point that seems to corroborate this finding is that only one study included in this review examined designers' involvement in and accountability for implementation.

\section{Purported Causes}

When actual practice is compared with ideal practice, a logical step is to analyze possible causal factors. The series of studies performed by Tessmer and Wedman (1992), Wedman and Tessmer (1993), Winer, Vasquez-Abad, and Tessmer (1994), and Mann (1996) did attempt to consider reasons for variations in practice. The reason that designers cited most frequently for not performing an activity was that decisions had already been made; these studies also identified contextual factors related to time, client support, and financial resources. Several studies consider designer-related factors as well. Winer, Vasquez-Abad, and Tessmer (1994) also compared the frequency with which activities were performed with the perceived necessity of each activity and found that task analysis and needs assessment activities were both least frequently performed and deemed least necessary (p. 5). Similarly, Visscher-Voerman and Gustafson (2004) discovered that when designers explained their reasons for performing activities in a certain order or eliminating activities altogether, their arguments illustrated contrasting views about the importance of these activities. Their second round of data analysis resulted in the proposal of four design paradigms: (1) an instrumental approach, focusing on the 
role of objectives; (2) a communicative approach, oriented towards consensus-making; (3) a pragmatic approach, emphasizing revision; and (4) an artistic approach, valuing creativity and connoisseurship (Visscher-Voerman \& Gustafson, 2004, p. 76). Additionally, designer expertise has been identified as a potential factor influencing ID practice variation. Rowland (1992) attributed the following variations in practice to the level of expertise: (1) the ways in which problems are interpreted, analyzed, and represented, (2) the ways and sorts of solutions that are generated, (3) designer interaction with both internal and external resources, and (4) basis for decision-making (p. 80). On the other hand Winer, Vasquez-Abad, and Tessmer (1994) found no significant differences at a.05 alpha level in design activity practice based on years of experience. Therefore, designer expertise may not influence the design activities that are performed, rather the way in which they are executed.

\section{Discussion}

At the outset of this literature review, we sought to learn whether gaps existed between the standards expressed in these competencies and instructional design practice. To these ends, our review revealed that:

- Needs assessments are conducted infrequently

- When needs assessment is conducted, it is performed in a variable or limited manner

- Development and weighing of alternative solutions vary from ID specifications

- Strategy selection, outcome identification, and test item development vary from ID specifications

- Tactics for selecting strategies, identifying outcomes, and developing test items development vary between designers

- Learner characteristic assessment is inconsistent 
- Formative and summative evaluations are not performed frequently

- Perceived accountability varies between designers

A second aim was to determine to what extent the IBSTPI competencies were being implemented. However, most of the studies reviewed here precede the publication of the 2001 revised IBSTPI competencies, making their utility for determining the competencies' degree of implementation is limited. Still, since the distinction between essential and advanced competencies was derived from a consensual approach aimed at the criticality of ID tasks, it is somewhat surprising to find so many ways that practice varies from standards on essential competencies. In fact, of the eight major gaps identified in our review, five of them seem to suggest that some of the essential competencies are not frequently used by instructional designers (e.g. needs assessment, evaluation, and implementation).

A third intention at the beginning of our review was to explore the causal explanations put forth in the literature for practice variation. For example, when exploring the reasons why instructional designers omitted various activities, Tessmer and Wedman (1992) and Wedman and Tessmer (1993) had respondents indicate which reasons influenced the elimination of a task. The reasons studied included: (a) lack of expertise, (b) client will not support it, (c) decision already made, (d) considered unnecessary, (e) not enough time, (f) not enough money (p. 46). Of these, most of the reasons are associated with contextual constraints. However, as lack of expertise and the perceived necessity of an activity might be interpreted as either organizational or designerrelated, no reason can be construed as solely a designer-related factor. Attribution theorists have long-considered the internal-external distinction to play a role in attribution of cause (Kelley \& Michela, 1980), which may give further reason to call into question the credibility of the external factors addressed in these studies. 
Another potential methodological issue is that these studies rely heavily upon on selfreported data. With the exception of Rowland (1992) and Kirschner, van Merriënboer, Sloep and Carr (2002) these studies made extensive use of survey and interview methods. Although Rowland (1992) and Kirschner, van Merriënboer, Sloep and Carr (2002) used observation methods, both relied on subjects' reports of intended actions. There are mixed findings on the validity of self-reported data (e.g. Des Jarlais, 1998; Jansen, van de Looij-Jansen, Ferreira, de Wilde, \& Brug, 2006; Molenaar, Van Ameijden, Grobbee, \& Numans, 2007). Given this, there is good reason to regard instructional designers' reports of actual or intended practice with skepticism. Table 4 provides a summary of some of the methodological issues for causal explanations of practice variation:

Table 4 Methodological Limitations of Reviewed Research

\begin{tabular}{|c|c|c|}
\hline Study (ies) & Description & Limitation(s) \\
\hline \multirow{4}{*}{$\begin{array}{l}\text { Holcomb, Wedman \& } \\
\text { Tessmer (1996) }\end{array}$} & Interviews of instructional & 1. Lack of anonymity \\
\hline & designers and their perceptions & 2. Self-reported data \\
\hline & $\begin{array}{l}\text { of how often design activities } \\
\text { are performed, their }\end{array}$ & 3. Convenience sample \\
\hline & $\begin{array}{l}\text { thoroughness, and related } \\
\text { success. }\end{array}$ & \\
\hline \multirow{4}{*}{$\begin{array}{l}\text { Kirschner, van } \\
\text { Merriënboer, Sloep \& } \\
\text { Carr (2002) }\end{array}$} & A study of 15 designers from & 1. Self-reported data \\
\hline & two organizations and divided & 2. Small convenience \\
\hline & into teams of two to three & sample \\
\hline & $\begin{array}{l}\text { members as they reported what } \\
\text { activities they would perform to } \\
\text { develop a course in response } \\
\text { to a hypothetical need. }\end{array}$ & 3. Limited task \\
\hline \multirow[t]{4}{*}{ Rowland (1992) } & A study of 8 novice and expert & 1. Self-reported data \\
\hline & $\begin{array}{l}\text { instructional designers that } \\
\text { involved task observation }\end{array}$ & $\begin{array}{l}\text { 2. Small Convenience } \\
\text { sample }\end{array}$ \\
\hline & participant verbalization, and & 3. Limited task \\
\hline & interviews. & $\begin{array}{l}\text { 4. Short observation } \\
\text { periods }\end{array}$ \\
\hline 1.Tessmer \& Wedman & Surveys of instructional & 1. Self-reported data \\
\hline (1992); & designers and their perceptions & 2. Samples of convenience \\
\hline 2. Wedman \& Tessmer & of how often they perform & 3. Unexpressed respondent \\
\hline
\end{tabular}


(1993)

3. Winer, Vasquez-

Abad \& Tessmer

(1994);

4. Mann (1996)

Visscher-Voerman \& Gustafson (2004) design activities as well as their characteristics reasons for not doing so.
Two phase study of 24 instructional designers involving survey, interviews, and validation methods.
1. Potential generalizability due to small convenience sample

2. One paradigm is not supported by data

\section{A Communicative Framework for Variation}

With regard to the original intentions of the review, the findings are somewhat disheartening. However, to this point we have mainly taken an instrumental approach—viewing ideal practice in the context of the IBSTPI standards. Despite this, it is not our position that these standards represent a formula for instructional design practice - a point alluded through the ironic usage of quotation marks when referring to "ideal" practice. Applying a communicative mindset, we distinguished between different types of variation, as shown in Table 5 .

Table 5

\section{Summary of Variation in ID Practice}

\begin{tabular}{|c|c|c|}
\hline & \multicolumn{2}{|c|}{ Type of variation } \\
\hline Domain & From standard & Between designer \\
\hline $\begin{array}{l}\text { Planning and } \\
\text { analysis }\end{array}$ & $\begin{array}{l}\text { - Needs assessments (NA) } \\
\text { are conducted infrequently. } \\
\text { When NA is conducted, it is } \\
\text { carried out in a limited } \\
\text { manner. } \\
\text { - Instructional designers } \\
\text { rarely develop and weigh } \\
\text { alternative solutions. }\end{array}$ & $\begin{array}{l}\text { - When NA is conducted, it is } \\
\text { performed in a variable } \\
\text { manner. } \\
\text { Development and weighing } \\
\text { of alternative solutions } \\
\text { varies between experts and } \\
\text { novices. } \\
\text { - Learner characteristic } \\
\text { assessment is inconsistent. }\end{array}$ \\
\hline $\begin{array}{l}\text { Design and } \\
\text { development }\end{array}$ & $\begin{array}{l}\text { The frequency with which } \\
\text { strategy selection, outcome } \\
\text { identification, and test item } \\
\text { construction are performed } \\
\text { by designers varies greatly. }\end{array}$ & \\
\hline
\end{tabular}


- Test item development and media decisions often generated to non-ID professionals.

\begin{tabular}{llll}
\hline $\begin{array}{l}\text { Formative and } \begin{array}{l}\text { summative } \\
\text { evaluation }\end{array} \\
\begin{array}{l}\text { Implementation } \\
\text { and management }\end{array}\end{array}$ & $\begin{array}{l}\text { Formative and summative } \\
\text { evaluations are not } \\
\text { performed frequently. }\end{array}$ & $\begin{array}{l}\text { Designers rarely play a role } \\
\text { in implementation yet plan } \\
\text { for it throughout the } \\
\text { process. }\end{array}$ & $\begin{array}{l}\text { Perceived accountability for } \\
\text { implementation varies } \\
\text { between designers. }\end{array}$ \\
\hline
\end{tabular}

Upon further reflection, we identified an additional type of variation which was not explicitly addressed in these findings: intra-designer variation. We propose a three-level framework for organizing research on variation in instructional design practice; this structure encompasses several types of variation including general, inter-designer, and intra-designer variation. This framework, relevant comparisons, and study issues associated with each type of variation are shown in Table 6.

Table 6

Variation Framework

\begin{tabular}{|c|c|c|}
\hline Type of & Comparison & Issue(s) of study \\
\hline \multirow[t]{2}{*}{ General } & $\begin{array}{l}\text { A standard practice, } S_{1} \text {, and actual } \\
\text { practices, } A_{1} \ldots A_{n}\end{array}$ & - Adoption of standards \\
\hline & $\begin{array}{l}\text { A standard practice, } S_{1} \text {, and one (or } \\
\text { more) non-standard practices } P_{n} \text {. } \\
\text { Where the frequency of } P_{n}>S_{1} \text {. }\end{array}$ & $\begin{array}{l}\text { - Content validity } \\
\text { - Causal explanations for } \\
\text { variation }\end{array}$ \\
\hline
\end{tabular}




\begin{tabular}{llll}
\hline Inter- & A number of practices, $P_{1} \ldots P_{n}$, & & Designer-related factors \\
designer & between designers. & affecting variation \\
& & - & External factors affecting \\
& & variation (i.e. resources \\
& & and context) \\
\hline Intra- & A number of practices, $P_{1} \ldots P_{n}$, & Contextual factors related \\
designer $\quad$ within individual designers, either & to variation \\
& across contexts or time) & Developmental factors \\
& & related to variation
\end{tabular}

This framework is generally useful as a schema for organizing streams of practice variation research within the ID literature. Additionally, as the next section reveals it can be applied as a framework for making recommendations.

\section{Application}

This section illustrates how our three-level variation framework can be applied as a lens for making recommendations. Before proceeding, we would like to note one limitation. Given the age of the data (most of the studies were published prior to the year 2000), their relevance to inferences about current day practice may be called into question. Moreover, given the sample sizes and convenient sampling methods employed, these findings may only have been generalizable to the instructional designer population at the time of publication in only a limited way. As such, we advocate that the reader view these as recommendations predominantly as illustrations. However, for those willing to accept the relevance of these data for current practice, we also provide tangible courses of action. 


\section{General Variation from Standards}

Our review of the literature indicated a number of marked deviations from IBSTPI standards. As previously noted, since most of the studies pre-date the publication of the 2001 revised IBSTPI competencies, their findings are not suitably applied to the question of the degree to which the IBSTPI competencies have been applied. However, at the time of writing, the revised IBSTPI competencies have been in publication for nearly a decade and study of their adoption is warranted.

Further issues related to general practice variation include the validity of the standards themselves and causal explanations for general variation. To the former point, we recall that our initial review made adjustments in the application of the IBSTPI competencies as a conceptual framework; therefore we would like to highlight that professional focus and evaluation be given greater consideration in future studies (and any re-visitation of the competencies by IBSTPI). Additionally, the number of variations from essential standards may also suggest that validation of the distinction between essential and advanced competencies merits study.

In further support of competency validation, we emphasize the importance of validation the IBSTPI competencies as normative standards.

\section{Inter-designer Variation}

Practices for needs assessment, developing alternative solutions, assessing learner characteristics, and accountability for implementation vary between designers. These discrepancies may suggest some practical implications for organizations in general and, to those who make decisions about the selection, supervision, development, and advancement of instructional designers in particular. For example, if accountability for implementation is expected of instructional designers' then it is worthwhile to include it as a criterion for selection. 
Additionally, development activities may be required to assist novices develop their skills for identifying and weighing options. Finally, procedure development and policy revisions may prove helpful in standardizing learner characteristic assessment and the execution of needs assessment.

\section{Intra-designer Variation}

This type of variation was identified post hoc as a logical complement to the other types of variation revealed by the literature review. Short of observed or reported intra-designer variations, our recommendations focus mainly on the utility of self-reflection. For instance, individual designers can reflect on the frequency with and degree to which they apply practices called for by the IBSTPI competencies. They ought to additionally consider their own attitudes about reasons for variation and how their practices have changed throughout their own careers. In order to effectively reflect, and produce usable data to refine design practice we recommend designers apply some of the tenets of design research (Reeves, Herrington \& Oliver (2004). This form of research involves several guidelines to improve instructional design practice through research. One of these principles specifically relevant to intra-design is for designers to "conduct rigorous and reflective inquiry to test and refine innovative learning, environments as well as to reveal new design principles" (p.59).

\section{Conclusion}

The present article reviewed literature on ID practice variation through the lens of the IBSTPI competencies. This framework employed comparisons of practice to the IBSTPI "ideals" and revealed gaps in all studied domains of practice. It also explored causal explanations for these deviations. Still, the age of the data and some methodological issues precluded broadbased conclusions about the adoption of the IBSTPI standards and causes for variation. This 
revealed the need for a shift from instrumental paradigm for practice variation to a more communicative approach

We proposed a three-level framework for ID practice variation that considers general variation from standards, between-designer variations, and variations within designers across contexts and time. This framework is suitable both as an organizer for the literature-base, but also as a structure for discussing recommendations. We support this claim through the application of our variation framework to the literature previously reviewed in this article.

We would like to acknowledge some potential limitations inherent in this review. Although the authors performed separate searches for recent relevant studies, we acknowledge the age of a number of studies. At issue is the extent to which possibly outdated findings are still relevant to current instructional design practice. This concern is partially addressed in our caution to the reader as the applied recommendations were introduced. Additionally, the age of the data present the risk that questions of ID practice variation no longer merit study. However, our proposal for considering different types of variation illustrates that many important issues for study still remain.

In closing, it be would be both impractical and unrealistic to recommend elimination of variation in ID practice. First, given the variety of job titles for its practitioners, one ought to expect some degree of variation. Furthermore, it is unlikely that specific ID methods could be explicated that would be effective in all situation, across all contexts. To the extent that practice variation represents an attempt to make instructional design more effective to the circumstancesat-hand, practice variation may actually be desirable, rather than a problem to be resolved.

\section{References}


Chase, C. A. (2002). The impact of gender differences and levels of expertise in instructional design (Doctoral dissertation). Dissertation Abstract International: Section A. 63(11), 3815.

Davidson-Shivers, G. V., \& Rasmussen, K. L. (2007). Competencies for instructional design and technology professionals. In R. A. Reiser \& J. V. Dempsey (Eds.), Trends and Issues in Instructional Design and Technology (pp. 271-286). Upper Saddle River, NJ: Pearson Education.

Des Jarlais, D. C. (1998). Validity of self-reported data, scientific methods and drug policy. Drug and Alcohol Dependence, 51(3), 265-266.

Dick, W., \& Johnson, R.B. (2007). Evaluation in instructional design: The impact of Kirkpatrick's four-level model. In R. A. Reiser \& J. V. Dempsey (Eds.), Trends and issues in instructional design and technology (2nd ed., pp. 94-103). Upper Saddle River, NJ: Pearson Prentice Hall.

Gustafson, K. L., \& Branch, R. M. (2002). Survey of instructional development models (4 ${ }^{\text {th }}$ ed.). Syracuse, NY: ERIC Clearinghouse on Information Resources.

Holcomb, C., Wedman, J. F., \& Tessmer, M. (1996). ID activities and project success: Perceptions of practitioners. Performance Improvement Quarterly, 9(1), 49-61.

Jansen, W., van de Looij-Jansen, P. M., Ferreira, I., de Wilde, E. J., \& Brug, J. (2006). Differences in measured and self-reported height and weight in Dutch adolescents. Annals of Nutrition \& Metabolism, 50(4), 339.

Johnson, C. B. (2005). Pedagogical patterns in required Masters level instructional design courses with reference to the IBSTPI competencies. (Doctoral dissertation). Dissertation Abstract International: Section A. 66(09), 3200. 
Kelley, H. H., \& Michela, J. L. (1980). Attribution Theory and Research. Annual Review of Psychology, 31, 457-501.

Kirschner, P. A., van Merrienboer, J., Sloep, P., \& Carr, C. (2002). How expert designers design. Performance Improvement Quarterly, 15(4), 86-104.

Larson, M. B., \& Lockee, B. B. (2004). Instructional design practice: Career environments, job roles, and a climate of change. Performance Improvement Quarterly, 17(1), 22-40.

Malopinksy, L. V., \& Osman, G. (2006). Dimensions of organizational change. In J. A. Pershing (Ed.), Handbook of human performance technology (3rd ed., pp. 262 -286). San Francisco, CA: Pfeiffer.

Molenaar, E. A., Van Ameijden, E. J. C., Grobbee, D. E., \& Numans, M. E. (2007). Comparison of routine care self-reported and biometrical data on hypertension and diabetes: Results of the Utrecht Health Project. European Journal of Public Health, 17(2), 199.

Molenda, M., \& Russell, J. D. (2006). Instruction as intervention. In J. A. Pershing (Ed.), Handbook of Human Performance Technology (pp. 335-369). San Francisco, CA: Pfeiffer.

Moseley, J. L., \& Hastings, N. B. (2005). Implementation: The forgotten link in the intervention chain. Performance Improvement, 44(4), 8-14.

Richey, R. C., Fields, D. C., \& Foxon, M. (2001). Instructional design competencies: The standards (3rd ed.). Syracuse, NY: ERIC Clearinghouse on Information and Technology. Rowland, G. (1992). What do instructional designers actually do? An initial investigation of expert practice. Performance Improvement Quarterly, 5(2), 65-86. 
Seels, B. B., \& Richey, R. C. (1994). Instructional technology: The definitions and domains of the field. Bloomington, IN: Association for Educational Communications and Technology.

Tessmer, M., \& Wedman, J. (1992). What designers do, don't do, and why they don't do it, Annual Meeting of the American Educational Research Association. San Francisco, CA.

Visscher-Voerman, I., \& Gustafson, K. L. (2004). Paradigms in theory and practice of education and training design. Educational Technology Research and Development, 52(2), 69-89.

Wedman, J., \& Tessmer, M. (1993). Instructional designers' decisions and priorities: A survey of design practice. Performance Improvement Quarterly, 6(2), 43-57.

Sims, R., \& Koszalka, T. (2008). Competencies for the new-age instructional designer. In Spector, J.M., Merrill, M.D., Merrienboer, J., \& Driscoll, M.P. (Eds.) Handbook of research on educational communications and technology $\left(3^{\text {rd }}\right.$ ed., pp.401 - 423) NY, New York: Lawrence Erlbaum Associates, Publishers.

Reeves, T. C., Herrington, J. \& Oliver, R. (2004). A development research agenda for online collaborative learning. Educational Technology, Research and Development, 52(4), 5365.

Rothwell, W. J. (1999). Roles, competencies, and outputs of human performance improvment. In W. J. Rothwell (Ed.), ASTD models for human performance improvement (2nd ed., pp. 17-32). Alexandria, VA: ASTD. 
